Article

\title{
The Nature of Laponite: Pure Hectorite or a Mixture of Different Trioctahedral Phases?
}

\author{
George E. Christidis ${ }^{1, *}$, Carlos Aldana ${ }^{2}$, Georgios D. Chryssikos ${ }^{3}$, Vassilis Gionis ${ }^{3}$, \\ Hussein Kalo ${ }^{4}$ (i), Matthias Stöter ${ }^{5}$, Josef Breu ${ }^{5}$ and Jean-Louis Robert ${ }^{6,+}$ \\ 1 School of Mineral Resources Engineering, Technical University of Crete, 73100 Chania, Greece \\ 2 Institut des Sciences de la Terre d'Orléans, CNRS, 1A Rue de la Ferollerie, 45100 Orléans, France; \\ aldana2362@gmail.com \\ 3 Theoretical and Physical Chemistry Institute, National Hellenic Research Foundation, \\ 48 Vass. Constantinou Ave., 11635 Athens, Greece; gdchryss@eie.gr (G.D.C.); vgionis@eie.gr (V.G.) \\ 4 BYK-Chemie GmbH, Stadtwaldstrasse 44, 85368 Moosburg, Germany; Hussein.kalo@altana.com \\ 5 Lehrstuhl für Anorganische Chimie I, Universität Bayreuth, 95440 Bayreuth, Germany; \\ Matthias.Stoter@uni-bayreuth.de (M.S.); Josef.Breu@uni-bayreuth.de (J.B.) \\ 6 IMPMC, Sorbonne Universités, UMR 7590, UPMC, CNRS, MNHN, IRD, 4 Place Jussieu, \\ CEDEX 05, 75231 Paris, France; Jean-Louis.Robert@impmc.upmc.fr \\ * Correspondence: christid@mred.tuc.gr \\ + Deceased.
}

Received: 30 June 2018; Accepted: 24 July 2018; Published: 26 July 2018

\begin{abstract}
A series of laponites and synthetic $\mathrm{OH}-$ and fluorinated hectorites prepared from hydrothermal and melting experiments at both industrial and laboratory scale were examined with XRD and FTIR (MIR and NIR) to determine their mineralogical composition and possible compositional heterogeneity. The end materials contained both $\mathrm{Li}$ - and Na-bearing phases. The industrial hydrothermal $\mathrm{OH}$-smectites prepared at low temperatures consist of random mixed layer hectorite-stevensite-kerolite with about $40-50 \%$ hectorite layers, the remaining being stevensite and kerolite at roughly equal proportions. The FTIR spectra of these smectites contain, besides the main $\mathrm{Mg}_{3} \mathrm{OH}$ stretching/overtone bands at 3695-3690 and 7225-7214 $\mathrm{cm}^{-1}$, respectively, additional $\mathrm{OH}$ overtone bands at $\sim 3716$ and $7265 \mathrm{~cm}^{-1}$ (hydrated state). These bands might be linked to $\mathrm{Mg}_{2} \mathrm{LiOH}$ stretching modes. The melt-derived smectites are kerolite-free but still contain stevensite layers, although the preparation methods involved heating in the excess of $1000{ }^{\circ} \mathrm{C}$. In these smectites Li might be partitioned to both octahedral and interlayer sites. Subsequent annealing of the melt-derived Mg-Li smectites caused migration of the exchangeable Li to the vacant octahedral due to the Hofmann-Klemen effect and thus decrease of the layer charge, as was indicated by the vO-D method. Hydrothermal synthesis of $\mathrm{Mg}$-Li smectites at high temperature $\left(400^{\circ} \mathrm{C}\right)$ and pressure (1 kbar), yielded pure hectorite without stevensite or kerolite domains.
\end{abstract}

Keywords: hectorite; stevensite; kerolite; laponite; synthesis; smectite nanoparticles

\section{Introduction}

The term laponite was introduced by the then Laporte Industries and appeared in scientific texts in the 1960s to describe synthetic hectorite-like clay minerals, utilized by the paint industry because of their excellent colloidal properties [1]. Since then the term is used as a synonym for synthetic hectorite nanoparticles. The currently acceptable definition suggests that laponite is a synthetic trioctahedral clay mineral with a hectorite-like composition and indicative structural formula $\mathrm{Na}_{0.7} \mathrm{Si}_{8} \mathrm{Mg}_{5.5} \mathrm{Li}_{0.3} \mathrm{O}_{20}(\mathrm{OH})_{4}[2,3]$. 
The first successful attempts for synthesis at low temperature reflux conditions [4-9] were followed by synthesis at higher temperatures using hydrothermal solutions or melts, using both $\mathrm{OH}$ and $\mathrm{F}$ anions at laboratory scale [3,10-18]. In addition, synthesis of organo-hectorites with different types of organic molecules has been achieved [19]. Similar hydrothermal approaches have been adopted by the industry. Differences in synthesis conditions are reflected in the physical and chemical properties of these materials and their applications see the reviews of $[3,18]$.

Synthetic hectorite nanoparticles are often manufactured at an industrial scale because they possess several advantages over their natural counterparts: (a) they have superior purity; (b) their physical and chemical properties may be tailored according to the specifications of the particular industry; (c) new varieties/species with superior properties which do not have natural analogues may be synthesized; and (d) there is need to preserve natural resources $[3,20]$. Thus, saponites and hectorites with layer charge higher than the typical layer charge of natural smectites $(0.2-0.6 \mathrm{e} / \mathrm{huc})$ have been synthesized by various laboratories [14-16,21]. Although the synthetic hectorites usually have very small particle size both in terms of crystallite diameter and quasicrystal thickness, typical of nanoparticles [22-25], certain synthetic approaches may yield single layer crystallites with very large surfaces of the order of tens of microns [14-16].

The end products of the aforementioned synthetic approaches have been characterized mainly by electron optical and spectroscopical methods and to a lesser degree by X-ray diffraction (XRD) and have been considered a priori as pure hectorites i.e., as homogeneous materials $[11,15,16,24]$ among others. Nevertheless, in a recent study based on detailed XRD analysis, a synthetic hectorite prepared for the CMS Source Clay Project by Southern Clay products Inc (SynL-1) was reported to contain stevensite layers in addition to hectorite [26]. The existence of vacancies is implied in the target structural formula for the synthetic Li-smectite [2,3]. In addition, the possible existence of vacancies in a synthetic product named laponite CP [27], might also be implied from the incomplete octahedral sheet provided in the structural formula, although the existence of vacancies was not addressed. These findings suggest that synthetic hectorites might be composites rather than pure phases. Composite phases might display different behavior in industrial applications than pure phases, if the individual components have different physical and chemical properties. Moreover their performance will be controlled by the compositional variability of the mixtures, i.e., by the relative abundance of the different components. In addition it would be important to display any possible differences in the composition of different laponites, which are targeted for certain industrial applications, to explain possible different properties. Therefore, it is the purpose of this contribution to characterize in detail a series of laponites produced by different industries, as well as a series of synthetic hectorites produced by various laboratories using different synthesis methods (hydrothermal solutions and melts) in order to determine if these materials are pure hectorites or consist of different phases.

\section{Materials and Methods}

\subsection{Materials}

Four different sets of laponite/synthetic hectorite samples were examined in this work. The first set, which includes laponite (hereafter LAP) B, D, ED, RD and JS, was supplied by BYK-Additives Ltd., Widnes, Chesite, UK. According to the chemical compositions provided by the supplier (Table 1) LAP D, ED and RD are OH-hectorites, whereas LAP B and JS contain fluorohectorites. The second set includes sample SynL-1 supplied by the CMS source clay project. The chemical composition of this sample (Table 1) was obtained from http:/ / www.clays.org/sourceclays_data.html. According to the aforementioned website, the clay was manufactured by the BYK USA Inc. Gonzales, TX, USA. 
Table 1. Sample abbreviations, chemical compositions (wt \%) and/or target structural formulae of the synthetic hectorites/laponites. LAP indicates laponite.

\begin{tabular}{|c|c|c|c|c|}
\hline \multicolumn{4}{|c|}{ First Sample Set (BYK-Chemie Ltd.) } & \multirow{2}{*}{$\begin{array}{c}\text { Second Sample Set (CMS Source } \\
\text { Clay Project) } \\
\text { SynL-1 }\end{array}$} \\
\hline & LAP D, ED and RD & LAP B & LAP JS & \\
\hline $\mathrm{SiO}_{2}$ & 59.5 & 55.0 & 50.2 & $57-61 \%$ \\
\hline $\mathrm{MgO}$ & 27.5 & 27.0 & 22.2 & $25-29 \%$ \\
\hline $\mathrm{Li}_{2} \mathrm{O}$ & 0.8 & 1.4 & 1.2 & $0.5-0.9 \%$ \\
\hline $\mathrm{Na}_{2} \mathrm{O}$ & 2.8 & 3.8 & 7.5 & $2.5-3.5 \%$ \\
\hline LOI & 8.2 & - & 8.7 & $<10 \%$ \\
\hline $\mathrm{P}_{2} \mathrm{O}_{5}$ & - & - & 4.8 & \\
\hline $\mathrm{F}$ & - & 5.6 & 5.4 & \\
\hline \multicolumn{5}{|c|}{ Third Sample Set (University of Bayreuth, Germany) } \\
\hline First group & \multicolumn{4}{|c|}{$\begin{array}{l}\text { Li0.4: } \mathrm{Li}_{0.4}\left[\mathrm{Mg}_{2.6} \mathrm{Li}_{0.4}\right] \mathrm{Si}_{4} \mathrm{O}_{10} \mathrm{~F}_{2} \\
\text { Li0.6: } \mathrm{Li}_{0.6}\left[\mathrm{Mg}_{2.4} \mathrm{Li}_{0.6}\right] \mathrm{Si}_{4} \mathrm{O}_{10} \mathrm{~F}_{2} \\
\text { Li0.8: } \mathrm{Li}_{0.8}\left[\mathrm{Mg}_{2.2} \mathrm{Li}_{0.8}\right] \mathrm{Si}_{4} \mathrm{O}_{10} \mathrm{~F}_{2}\end{array}$} \\
\hline Second group & \multicolumn{4}{|c|}{ Na0.5, Na0.5-ANN, Na0.5-HTT: $\mathrm{Na}_{0.5}\left[\mathrm{Mg}_{2.6} \mathrm{Li}_{0.5}\right] \mathrm{Si}_{4} \mathrm{O}_{10} \mathrm{~F}_{2}$} \\
\hline Third group & \multicolumn{4}{|c|}{ Na0.33: $\mathrm{Na}_{0.33}\left[\mathrm{Mg}_{2.67} \mathrm{Li}_{0.33}\right] \mathrm{Si}_{4} \mathrm{O}_{10} \mathrm{~F}_{2}$} \\
\hline \multicolumn{5}{|c|}{ Fourth Sample Set IMPMC, CNRS, Paris, France } \\
\hline \multicolumn{5}{|c|}{ Na0.4: $\mathrm{Na}_{0.4}\left(\mathrm{Mg}_{2.6} \mathrm{Li}_{0.4}\right) \mathrm{Si}_{4} \mathrm{O}_{10}(\mathrm{OH})_{2}$} \\
\hline
\end{tabular}

The third set includes fluorohectorites prepared in the Department of Inorganic Chemistry, University of Bayreuth, Germany, using the melt synthesis methods described previously $[15,16]$. It consists of three groups: The first group of samples $\mathrm{Li0.4,} \mathrm{Li} 0.6$, and Li0.8 contain $\mathrm{Li}$ both in the octahedral sheet and the interlayer as was described by [15]. The number notations correspond to the target layer charge of the hectorites, i.e., 0.4 electrons per half unit cell (e/huc), $0.6 \mathrm{e} / \mathrm{huc}$ and $0.8 \mathrm{e} / \mathrm{huc}$, respectively. The second group includes samples Na0.5, Na0.5-ANN and Na0.5-HTT. Sample Na0.5 is a fluorohectorite with layer charge $0.5 \mathrm{e} /$ huc and interlayer $\mathrm{Na}$. Sample Na0.5-ANN was prepared from $\mathrm{Na} 0.5$ after annealing at $1050{ }^{\circ} \mathrm{C}$ for six weeks, whereas Na0.5-HTT was derived from Na0.5 after hydrothermal treatment at $250{ }^{\circ} \mathrm{C}$ for six weeks [16]. These samples are, therefore, supposed to have the same structural formula as $\mathrm{Na} 0.5$, because they have the same chemical composition (Table 1). The third group of the second set includes sample $\mathrm{Na} 0.33$, derived from a synthetic fluorostevensite with target layer charge $~ 0.44-0.47$ e/huc [28], which subsequently underwent Mg-exchange, heating at $250{ }^{\circ} \mathrm{C}$ and then back-exchange of the exchangeable $\mathrm{Mg}$ with $\mathrm{Na}$. This treatment is supposed to have decreased the layer charge to 0.33 e/huc. Note that sample $\mathrm{Na} 0.33$ was not characterized as hectorite [28]. The target composition of the fluorohectorites of the third set are listed in Table 1.

Finally, the fourth set includes $\mathrm{Na} 0.4$, a synthetic Na-hectorite with 0.4 octahedral Li-atoms prepared at IMPMC, CNRS, Paris, France (Na0.4). The hectorite was prepared by hydrothermal synthesis of gels of appropriate composition at $400{ }^{\circ} \mathrm{C}$ under $1 \mathrm{kbar}$ water pressure for four weeks in Morey-type externally heated pressure vessels [29]. The target structural formula is shown in Table 1.

\subsection{Methods}

The mineralogical composition of the synthetic hectorites was determined by $\mathrm{XRD}$, based on the distinction of the three types of trioctahedral smectites from their different response to thermal treatment and glycerol solvation after Cs-saturation [26]. Stevensite collapses when heated at $500{ }^{\circ} \mathrm{C}$ and does not swell in ethylene glycol vapours, whereas saponite and hectorite are not affected. The saponite and hectorite are distinguished by glycerol solvation after Cs-saturation. Saponite forms single layer complexes after glycerol solvation, whereas hectorite forms double layer complexes. Stevensite yields (001) diffraction maxima with intermediate d-spacings between single and double 
layer complexes, which increase with solvation time, due to steric effects. Only the heating treatment was utilized in the present study, because the synthetic smectites were free of Al and Fe (Table 1); hence saponite could not be present, rendering the Cs-saturation unnecessary.

The $<2 \mu \mathrm{m}$ fraction was separated by settling and dried on glass slides at room temperature. Three preparations were made for each sample: air dried, solvated with ethylene glycol (EG) vapor at $60{ }^{\circ} \mathrm{C}$ overnight to ensure maximum saturation and heated at $500{ }^{\circ} \mathrm{C}$ for $90 \mathrm{~min}$ followed by solvation with EG-vapor at $60^{\circ} \mathrm{C}$ overnight. XRD analysis was performed from 2 to $35^{\circ} 2 \theta$, with a Bruker D8 Advance XRD instrument, equipped with a Lynx Eye strip silicon detector, using Ni filtered CuK $\alpha$ radiation $(35 \mathrm{kV}, 35 \mathrm{~mA}), 0.298^{\circ}$ divergence and antiscatter slits, and a step size of $0.019^{\circ} 2 \theta$, with $47.7 \mathrm{~s}$ count time per step. The collected data were evaluated with the $\mathrm{EVA}^{\circledR}$ software provided by SOCABIM. The relative humidity in the laboratory during sample preparation and XRD experiment was 38-40\%.

The IR spectra were measured on a Fourier transform spectrometer (Equinox 55S by Bruker $\mathrm{GmbH}$, (Ettlingen, Germany) from thin oriented films, deposited by drying clay suspensions on a single-reflection, diamond ATR element (DurasamplIR2 by SensIR). Near-infrared (NIR) measurements were performed in the diffuse reflectance mode via an optical fiber bundle on a Fourier transform instrument (Vector 22, Bruker). A homemade environmental cell [30] enabled sample equilibration at variable relative humidity from $\sim 5$ up to $\sim 85 \% \mathrm{RH}$. The same cell was suitable for saturation with $\mathrm{D}_{2} \mathrm{O}$, needed for the measurement of layer-charge diagnostic bands (OD method of [31]). Both ATR and NIR spectra were averages of 200 scans at an optical resolution of $4 \mathrm{~cm}^{-1}$ $\left(\Delta v=2 \mathrm{~cm}^{-1}\right)$. Peak maxima were determined accurately by second-derivative analysis.

\section{Results}

\subsection{XRD Results}

The different sets of samples yielded different XRD traces. Representative XRD traces of the air-dried samples are shown in Figure 1. The BYK-Chemie laponites are characterized by a broad 001 diffraction maximum of smectite with a $\mathrm{d}_{001}$ spacing of $12.6-13.5 \AA$, typical of Na-smectites at the relative humidity recorded during the experiments [32]. These diffraction characteristics were observed both for the $\mathrm{OH}$-and the F-bearing smectites (Figure 1a). The large FWHM of the 001 maxima are indicative of both variable degree of hydration of the smectite layers and very small particle sizes. The SynL-1 smectite displays almost identical XRD pattern as the BYK-Chemie laponites (Figure 1a).
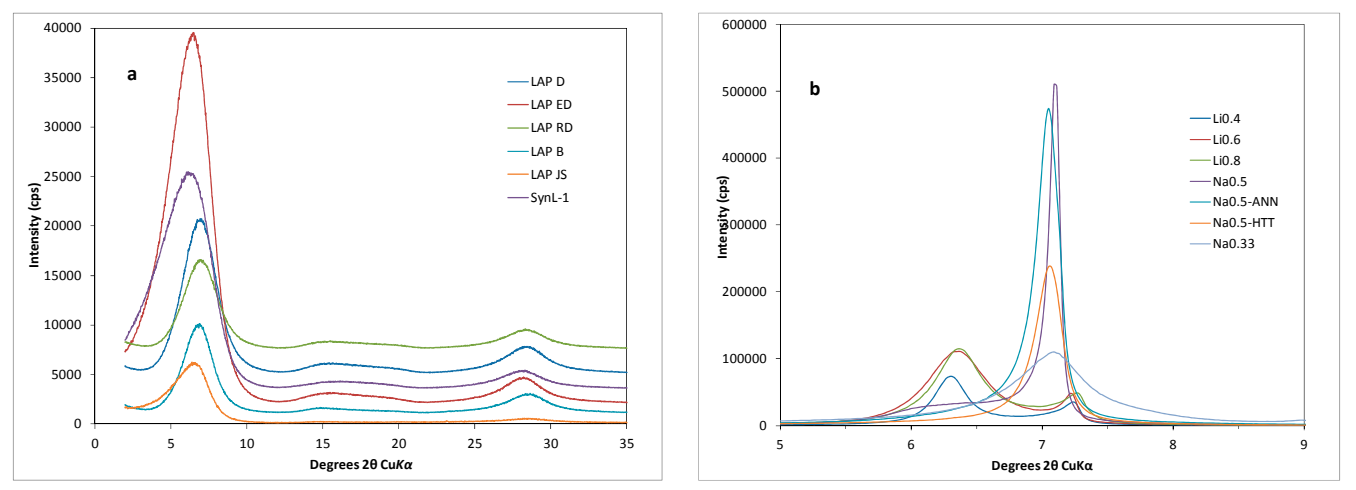

Figure 1. XRD traces of the air-dried synthetic Mg-Li smectites. (a) Samples from the first and second sample sets; and (b) samples from the third sample set.

The air-dried synthetic smectites from the third sample set (University of Bayreuth) display distinctively different XRD traces and are better crystallized than their industrial counterparts (Figure 1b). Note that this is true also for sample Na0.5-ANN, the structure of which did not collapse despite the fact that its annealing temperature $\left(1050{ }^{\circ} \mathrm{C}\right)$ was considerably higher than 
the release temperature of fluorine reported for natural hectorite i.e., $\sim 850-900{ }^{\circ} \mathrm{C}$ [33]. The Li0.4-Li-0.8 series (first group) is characterized by a well-defined 001 doublet, centered at 12.3 and $14.3 \AA$, indicative of single- and double-layer hydrates, with the double layer hydrate dominating. Both 001 diffraction maxima are sharp with very narrow FWHM, in accord with the large particle size of these smectites $[15,16]$. The Na0.5 (second group) also displays a 001 doublet; however the single-layer hydrate is more pronounced than its double-layer counterpart, which is broad (Figure 1b). The Na0.5-ANN is characterized by a single layer hydrate. Finally the hydrothermally treated Na0.33 sample is characterized by a single layer hydrate and a satellite peak at $9.8 \AA$. The synthetic smectite of the fourth sample set, prepared hydrothermally at higher temperatures is more uniform and characterized by a diffraction maximum at $\sim 12.5 \AA$ typical for single layer hydrate complex of $\mathrm{Na}$ cations (data not shown). The diffraction maxima are also sharp with narrow FWHM.

Ethylene glycol solvation confirmed the different nature of the various sample sets. The BYK-Chemie and SynL-1 OH-smectites display interstratification between a swelling and a non-swelling component (Figure 2a). The diffraction maxima are broad and display irrational higher order basal peaks typical of peak migration. X-ray diffraction trace modeling with NEWMOD code [34], using an R0 mixed-layer trioctahedral smectite-kerolite with 75\% smectite layers reproduced the experimental traces (Figure 2a). Therefore the low temperature hydrothermal synthesis employed in the industrial practice did not produce solely swelling layers. The F-bearing smectites displayed different characteristics. LAP B was similar to the $\mathrm{OH}$-bearing smectites, being characterized by an $\mathrm{R} 0$ mixed-layer trioctahedral smectite-kerolite with 75\% smectite layers, whereas LAP JS seemed to be kerolite-free (Figure 2a).
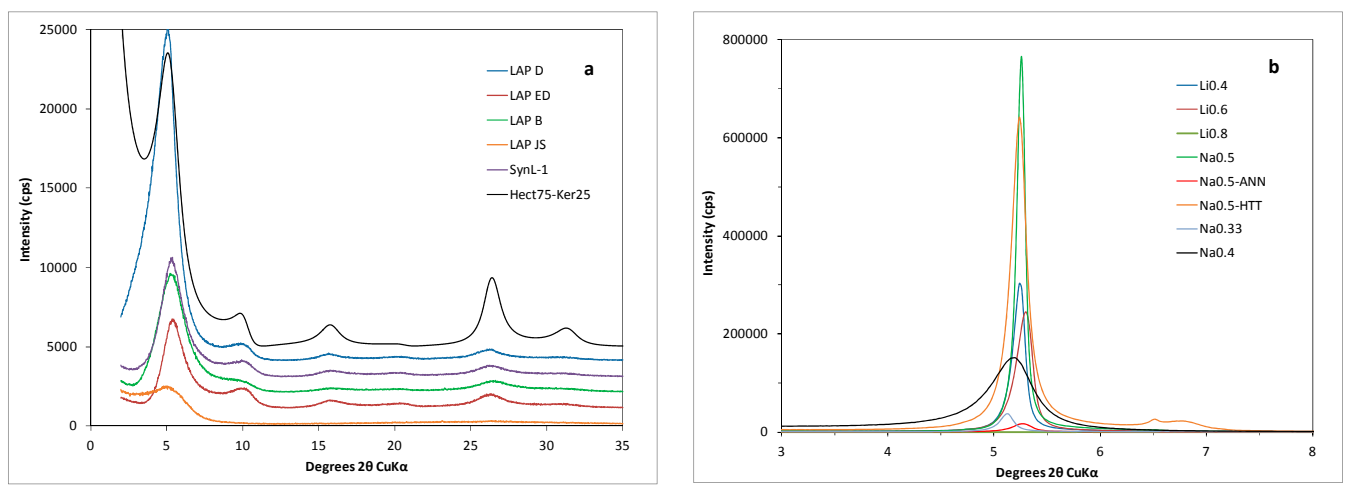

Figure 2. XRD traces of the EG-solvated synthetic Mg-Li smectites. (a) Samples from the first and second sample sets, the Hect75-Ker25 is the fitting trace of R0 mixed layer smectite-kerolite obtained by Newmod code; (b) Samples from the third and fourth sample sets.

In contrast, the smectites prepared by melt-synthesis (third sample set) and high temperature-hydrothermal synthesis (fourth sample set) yielded only swelling layers with double layer EG complexes (Figure 2b). The Na0.5-HTT sample contains traces of single layer EG complexes. The XRD traces are characterized by well-defined sharp peaks, with narrow FWHM, indicating large particle sizes, in accord with previous work [15,16]. The hydrothermal smectite of the fourth set ( $\mathrm{Na} 0.4)$ has a broader 001 diffraction maximum than its counterparts derived from melt synthesis. Also, the higher order basal peaks display rational d-spacings, indicating a lack of interstatification with non-swelling phases.

Heating of the synthetic smectites at $500{ }^{\circ} \mathrm{C}$ followed by EG-solvation revealed further heterogeneity of the synthetic smectites (Figure 3). The $\mathrm{OH}$-smectites from BYK-Chemie and the SynL-1 are characterized by diffraction maxima at $\sim 10 \AA$ and $\sim 18-16 \AA$, with the maximum at $10 \AA$ being dominant (Figure 3 ). This diffraction maximum corresponds to the smectite layers which collapsed during heating plus the original kerolite layers. All these layers form a discrete collapsed 
phase. The swelling layers (i.e., hectorite) should not exceed $~ 50 \%$ of the total clay layers present in the samples. In contrast the F-smectites are richer in the swelling component (Figure 3): LAP B contains only 10-20\% discrete collapsed layers, whereas LAP JS is free of discrete collapsed layers (data not shown). Nevertheless both types of F-smectites may contain collapsed layers randomly interstratified with swelling hectorite layers. Indeed in laponite $\mathrm{B} \mathrm{d}_{003}$ does not display rationality when compared to $\mathrm{d}_{001}$.

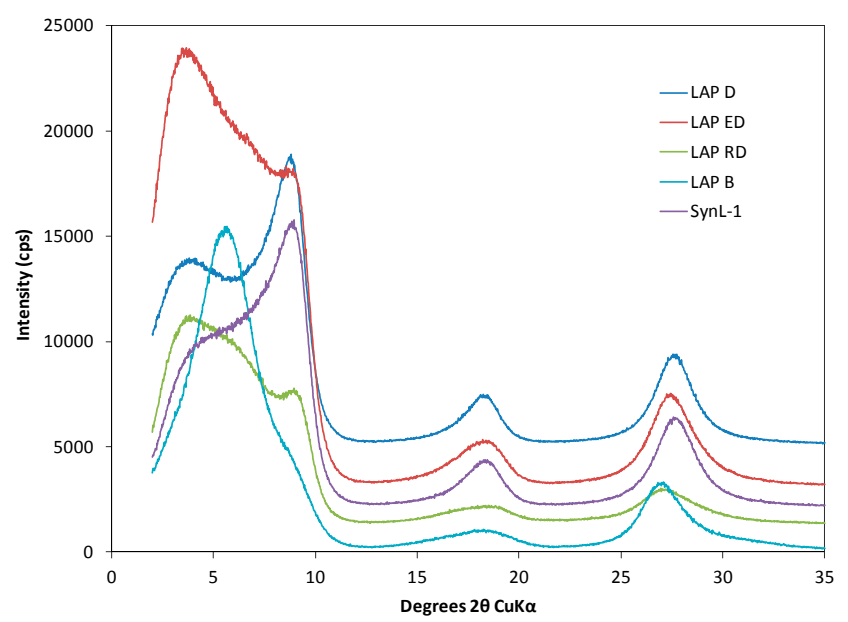

Figure 3. XRD traces of the synthetic Mg-Li smectite samples from first and second sample sets after heating at $500{ }^{\circ} \mathrm{C}$ and subsequent EG solvation.

The synthetic smectites from the third sample set display a different behavior after heating at $500{ }^{\circ} \mathrm{C}$ followed by EG-solvation (Figure 4). They all contain discrete collapsed layers, the abundance of which decreases with increasing layer charge. Based on the relative intensities of the 001 peak for the swelling and the collapsed phase (hectorite and stevensite, respectively) the stevensite layers are $\sim 10 \%, 1.5 \%$ and $0.5 \%$ in $\mathrm{Li0} .4, \mathrm{Li} 0.6$ and $\mathrm{Li} 0.8$ respectively. The $\mathrm{Na} 0.5$ series display also different behavior, with the collapsed stevensitic layers being most abundant in $\mathrm{Na} 0.5$ ( $35 \%)$. After annealing, the material (Na0.5-ANN) still contains detectable $(\sim 0.3 \%)$ stevensite layers, whereas the hydrothermally-treated $\mathrm{Na} 0.5$ ( $\mathrm{Na} 0.5-\mathrm{HTT}$ ) is stevensite-free. The synthetic smectite from the fourth sample set (Na0.4) contains only swelling layers (hectorite) and is free of stevensite (Figure 4 inset).

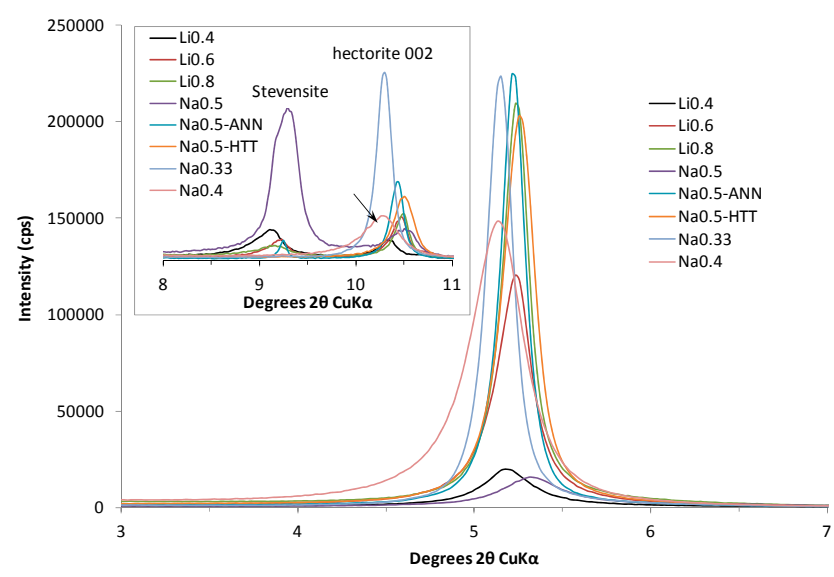

Figure 4. XRD traces of the synthetic Mg-Li smectite samples from third and fourth sample sets after heating at $500{ }^{\circ} \mathrm{C}$ and subsequent EG solvation. The inset indicates the separation of the collapsed (stevensite) layers from the 002 diffraction maximum of hectorite. The arrow in the inset indicates sample Na0.4 (fourth sample set). 


\subsection{Structural Formula of the BYK-Chemie OH-Laponites}

The structural formula of the LAP D, ED and RD samples, which according to the manufacturer have identical chemical composition, was calculated from the chemical analyses provided with the samples (Table 1). Assuming that the material consists only of smectite and that all Li resides in octahedral sites, the calculated structural formula of the laponites is $\mathrm{Na}_{0.36}\left(\mathrm{Mg}_{2.74} \mathrm{Li}_{0.22} \square_{0.04}\right) \mathrm{Si}_{3.99} \mathrm{O}_{10}(\mathrm{OH})_{2}$. The layer charge of this phase obtained from the structural formula is $0.34 \mathrm{e} / \mathrm{huc}$. This composition is different from the aforementioned indicative formula suggested by the CMS nomenclature committee in two aspects: The BYK-Chemie OH-smectites have higher Li-content and lower amount of vacancies than the suggested structural formula, i.e., they are closer to the hectorite end-member from a mineral chemistry point of view.

The XRD analysis of the BYK-Chemie laponites and SynL-1 has suggested that these contain $\sim 25 \%$ kerolite layers (Figure 2a) that need to be compensated for in the structural formula. The kerolite from Madison County, NC, USA, was used as the reference due to its pure chemical composition [35]. This kerolite is essentially free of $\mathrm{Al}, \mathrm{Fe}$, and $\mathrm{Ni}$, consisting essentially of $\mathrm{Mg}$ and $\mathrm{Si}$, i.e., it is very close to the composition of the synthesis mixtures of the synthetic phases of the present study (Table 1). As ideal kerolite is neutral, the structural formula obtained for the swelling smectitic phase of LAP D, LAP ED, LAP RD, and SynL-1 is $\mathrm{Na}_{0.49}\left(\mathrm{Mg}_{2.60} \mathrm{Li}_{0.29} \square_{0.11}\right) \mathrm{Si}_{4} \mathrm{O}_{10}(\mathrm{OH})_{2}$. This composition indicates that both hectorite and stevensite are present in these samples. From the magnitude of the octahedral layer charge it can be estimated that $\sim 60 \%$ of the smectitic phase might belong to hectorite and $\sim 40 \%$ to stevensite.

\subsection{IR Results}

\subsubsection{Structural OH Groups}

Mid- and near-infrared spectra reveal clearly that the only samples with a full spectrum of structural $\mathrm{OH}$ are LAP D, -ED and-RD from the first sample set, SynL-1 from the second sample set (all identical to each other) and $\mathrm{Na} 0.4$ from the fourth sample set (Figure 5). The samples LAP B and LAP JS exhibit a weak structural $\mathrm{OH}$ signature, suggesting that they are partly fluorinated. This is at odds with the chemical composition provided by BYK-Chemie, which indicates an OH-free product (Table 1). Samples LAP B and LAP JS are also identical to each other, with the exception of an additive (presumably a Na-pyrophosphate hydrate) in the latter. All the remaining samples from the third sample set are fully fluorinated, lacking the $\mathrm{OH}$ which are valuable proxies of octahedral structure, also in accordance with the target structural formulae (Table 1).

Interestingly, the vibrational spectra of the $\mathrm{OH}$-containing samples measured at ambient conditions are not suitable for rigorous material identification. This is because they invariably appear as a convolution of two forms with discrete spectra that can be obtained pure at $\sim 80 \% \mathrm{RH}$ ("wet") and $\sim 5 \% \mathrm{RH}$, purging by dry $\mathrm{N}_{2}$ or heating $>120^{\circ} \mathrm{C}$ ("dry"). The main $\mathrm{Mg}_{3} \mathrm{OH}$ stretching and bending fundamentals shift by $\sim 10 \mathrm{~cm}^{-1}$ in opposite directions upon drying (Table 2). As a result, the $(v+\delta)$ $\mathrm{Mg}_{3} \mathrm{OH}$ remains practically constant, both within a wetting-drying series of measurements, but also among different samples (Table 2).

In the laponites from the first and second sample sets, $v \mathrm{Mg}_{3} \mathrm{OH}$ shifts from 3690 to $3681 \mathrm{~cm}^{-1}$ upon drying, whereas the hectorite from the fourth sample set shifts from 3695 to $3684 \mathrm{~cm}^{-1}$ (Table 2). The corresponding overtones display larger shifts, from 7214 to 7194 , and from 7225 to $7203 \mathrm{~cm}^{-1}$, respectively (anharmonicity $X \approx 83-84 \mathrm{~cm}^{-1}$ in all cases). All these changes are fully reversible upon rehydration. Shifts of the same magnitude are reported in sepiolite and trioctahedral-rich palygorskite, but are absent from talc [28-32,34-36]. The exact stretching, bending and overtone positions of $\mathrm{Na} 0.4$ (fourth sample set) differ by $5-7 \mathrm{~cm}^{-1}$ from those of synthetic laponites (first and second sample sets). Interestingly, a study of hydration of a natural hectorite from Hector, CA [37], reported $\delta$ and $v$ $\mathrm{Mg}_{3} \mathrm{OH}$ modes shifting from 645 to $655 \mathrm{~cm}^{-1}$ and from 3690 to $3680 \mathrm{~cm}^{-1}$, respectively, upon drying. These positions are nearly identical to those of laponite and differ from those of the Na0.4 (Table 2). 


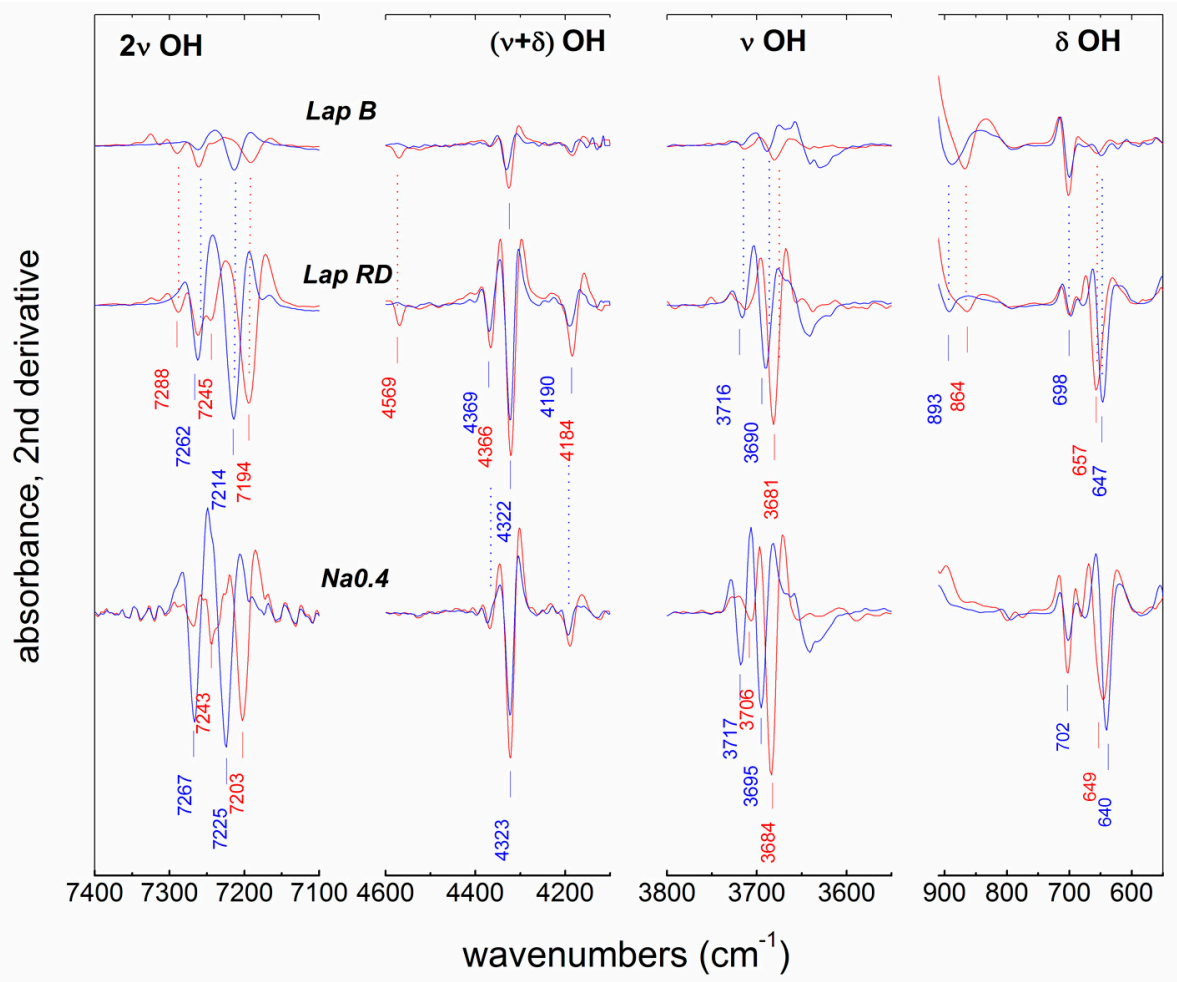

Figure 5. Details of the second derivative ATR and NIR absorbance spectra of LAP B, LAP RD, and Na0.4 over the bending, stretching, combination and overtone ranges of structural OH. The "wet" and "dry" spectra are depicted in blue and red, respectively. The spectrum at ambient conditions is intermediate to the two end-members. The spectral pairs are offset for clarity but share the same $\mathrm{y}$-axis scale.

Table 2. Characteristic positions $\left(\mathrm{cm}^{-1}\right)$ of stretching, bending, combination and overtone modes of structural $\mathrm{OH}$ in "wet" and "dry" non-fluorinated smectites. Anharmonicities (X) are also provided. Talc and sepiolite (SepSp-1) data are added for comparison (from [30]).

\begin{tabular}{|c|c|c|c|c|c|c|c|}
\hline & \multicolumn{2}{|c|}{$\begin{array}{l}\text { LAP D, -ED, -RD, } \\
\text { LAP B, -JS, SynL-1 }\end{array}$} & \multicolumn{2}{|c|}{$\mathrm{Na} 0.4$} & \multirow[t]{2}{*}{ Talc } & \multicolumn{2}{|c|}{ SepSp-1 } \\
\hline & Wet & Dry & Wet & Dry & & Wet & Dry \\
\hline \multirow{2}{*}{$2 v(X)$} & $7262(85)$ & $7245(84)$ & $7267(84)$ & $7243(85)$ & - & - & - \\
\hline & 7214 (83) & $7194(84)$ & 7225 (83) & 7203 (83) & $7184(84)$ & $7214(83)$ & 7194 (83) \\
\hline$v+\delta$ & 4322 & 4322 & 4323 & 4323 & 4324 & 4324 & 4327 \\
\hline \multirow[b]{2}{*}{$v$} & 3716 & 3706 & 3717 & 3706 & - & - & - \\
\hline & 3690 & 3681 & 3695 & 3684 & 3676 & 3690 & 3680 \\
\hline$\delta$ & 647 & 657 & 640 & 649 & 669 & 644 & 654 \\
\hline
\end{tabular}

In addition to the $\mathrm{Mg}_{3} \mathrm{OH}$ modes, the smectites from the first, second and fourth sample sets exhibit an additional set of $\mathrm{OH}$ stretching overtone bands at $\sim 3716,7265 \mathrm{~cm}^{-1}$ (wet), which shift reversibly to $\sim 3706,7245 \mathrm{~cm}^{-1}$ upon drying while maintaining nearly constant anharmonicity, $X=84-85 \mathrm{~cm}^{-1}$ (Table 2). The relative intensity of these bands is strongest in the wet Na0.4 sample from the fourth sample set. The 3716 and $3706 \mathrm{~cm}^{-1}$ fundamentals have been observed in natural hectorite [37] and have been attributed to $\mathrm{Mg}_{2} \mathrm{Li}(\mathrm{OH})$ species perturbed by interlayer cations. As such, they must constitute a signature specific to the hectoritic component in trioctahedral smectite. The same 
assignment to $\mathrm{Mg}_{2} \mathrm{Li}(\mathrm{OH})$ species was proposed by [38] who studied LAP RD in KBr pellet form and observed $\mathrm{Mg}_{3} \mathrm{OH}$ fundamental and overtone bands at $3706 / 7250 \mathrm{~cm}^{-1}$ and the $3684 / 7214 \mathrm{~cm}^{-1}$.

Last, all industrial synthetic smectites (first and second sample sets) develop upon drying sharp new bands at $\sim 4570$ and $7285-80 \mathrm{~cm}^{-1}$, which are absent from the corresponding spectra of the synthetic hectorite Na0.4 (Figure 5). By analogy to palygorskite and sepiolite [36], these bands are attributed to $\mathrm{SiOH}$ termination defects of the tetrahedral sheet.

\subsubsection{Fluorinated Hectorite}

The aforementioned analysis is not applicable to the fully fluorinated smectites of the third sample set, because these were found to lack structural $\mathrm{OH}$. Only the vibrational signature of the silicate network and interlayer species can be observed, and spectral differences among most of these samples are small. The ATR spectra of the seven fluorinated hectorites are compiled in Figure 6. They are measured from fully $\mathrm{D}_{2} \mathrm{O}$ hydrated samples, also employed for estimating layer charge (see Section 3.3.3), and are dominated by the strong Si-O stretching envelope at $\sim 1000 \mathrm{~cm}^{-1}$ (the weak feature at $\sim 1205 \mathrm{~cm}^{-1}$ is due to $\delta \mathrm{D}_{2} \mathrm{O}$ ). Samples Li0.4, Li0.6, Li0.8, Na0.33, and Na0.5 have similar spectra with complex Si-O profiles which are biased by optical dispersion effects due to the strong absorption coefficient of the Si-O stretch. These profiles are dependent on sample uniformity and particle size, the latter affecting orientation. In striking difference with the above, the Na0.5-ANN sample displays two discrete sharp bands at 1003 and $1088 \mathrm{~cm}^{-1}$ (presumably due to in-plane and out-of-plane $v \mathrm{Si}-\mathrm{O}$, respectively), suggesting great particle uniformity and excellent orientation, similar to the phyllosilicates in Langmuir-Blodgett monolayers [39]. The Na0.5-HTT sample appears also uniform but is, perhaps, less oriented on the ATR crystal.

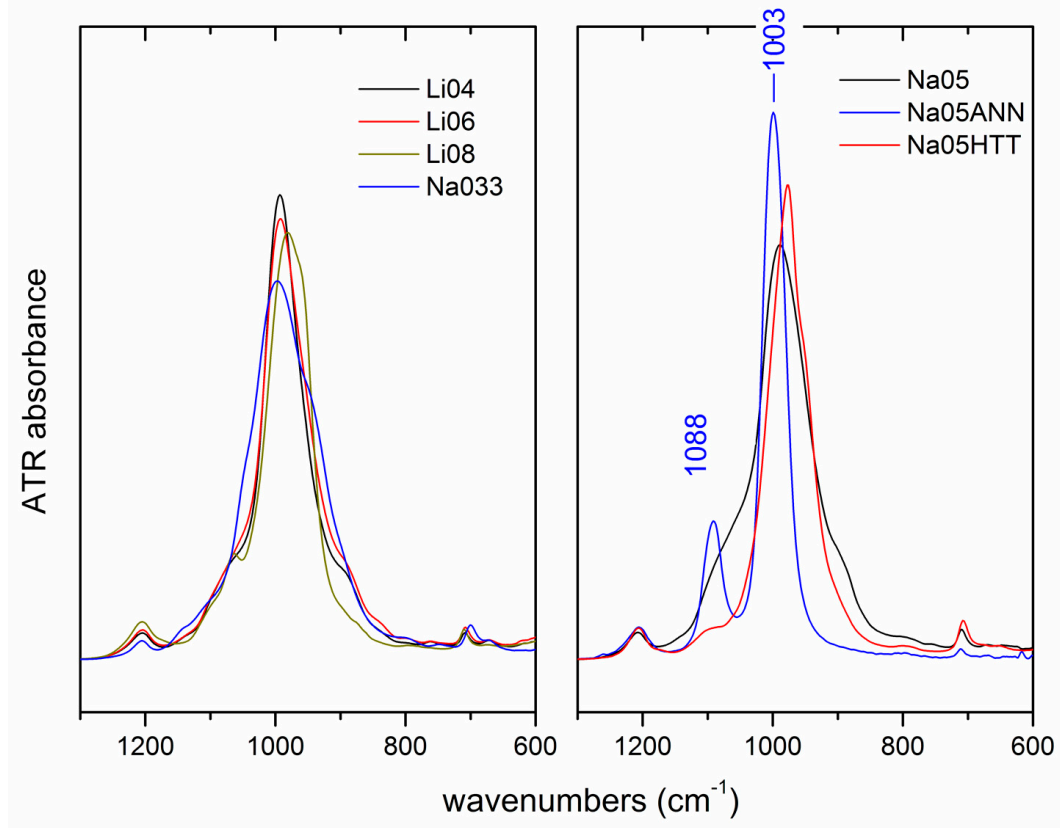

Figure 6. Detail of the ATR spectra of the fluorinated hectorites from third sample set. The spectra were taken from samples fully hydrated with $\mathrm{D}_{2} \mathrm{O}$ and have been subjected to intensity normalization.

\subsection{3. $\mathrm{D}_{2} \mathrm{O}$ Exchange and Layer Charge Determination}

Clear $v \mathrm{O}-\mathrm{D}$ bands are observed in all samples hydrated with $\mathrm{D}_{2} \mathrm{O}$ (e.g., Figure 7), regardless of the $\mathrm{OH} / \mathrm{F}$ ratio in the octahedral sheet. The $\nu \mathrm{O}-\mathrm{D}$ positions determined according to [30] are listed in Table 3. Note that the existing calibration of layer charges against $\nu \mathrm{O}-\mathrm{D}$ does not include trioctahedral smectites. For this reason, the layer charge values in Table 3 are given as "apparent", $\mathrm{Q}_{\mathrm{app}}$. The characteristic $\nu \mathrm{O}-\mathrm{D}$ wavenumbers of industrial samples LAP D, ED, RD and SynL-1 are very 
similar pointing to layer charges that are identical within error $(0.38 \pm 0.02 \mathrm{e} / \mathrm{huc})$. Similarly, samples LAP B and LAP JS are identical to each other but have a higher layer charge ( $Q_{a p p}=0.58 \pm 0.02 \mathrm{e} / \mathrm{huc}$ ). The remaining samples have broadly distributed values of $Q_{a p p}$ ranging from $0.35 \pm 0.02 \mathrm{e} / \mathrm{huc}$ $(\mathrm{Na} 0.33)$ to $0.65 \pm 0.02 \mathrm{e} / \mathrm{huc}(\mathrm{Na} 0.5)$. The annealing and hydrothermal treatments of the $\mathrm{Na} 0.5$ sample have a clear effect on layer charge (samples Na0.5-ANN and-HTT). Last, differences may be observed between targeted and measured layer charges in the Li0.4-Li0.8 series (third sample set).

Table 3. Position of $\vee \mathrm{O}-\mathrm{D}$ stretch $\left(\mathrm{cm}^{-1}, \pm 0.2\right)$ per [31] and apparent layer charge (Qapp, e/huc, \pm 0.02$)$. See text for details.

\begin{tabular}{ccc}
\hline & vO-D, $\mathbf{c m}^{-\mathbf{1}}$ & Q $_{\text {app }}$, e/huc \\
\hline LAP D & 2693.6 & 0.37 \\
LAP ED & 2692.9 & 0.39 \\
LAP RD & 2692.5 & 0.40 \\
LAP B & 2686.6 & 0.58 \\
LAP JS & 2686.5 & 0.58 \\
SynL-1 & 2693.6 & 0.37 \\
Na0.5 & 2684.2 & 0.65 \\
Na0.5-ANN & 2690.9 & 0.45 \\
Na0.5-HTT & 2687.0 & 0.57 \\
Li0.4 & 2688.8 & 0.52 \\
Li0.6 & 2688.7 & 0.52 \\
Li0.8 & 2685.8 & 0.61 \\
Na0.33 & 2694.3 & 0.35 \\
Na0.4 & 2690.2 & 0.47 \\
\hline
\end{tabular}

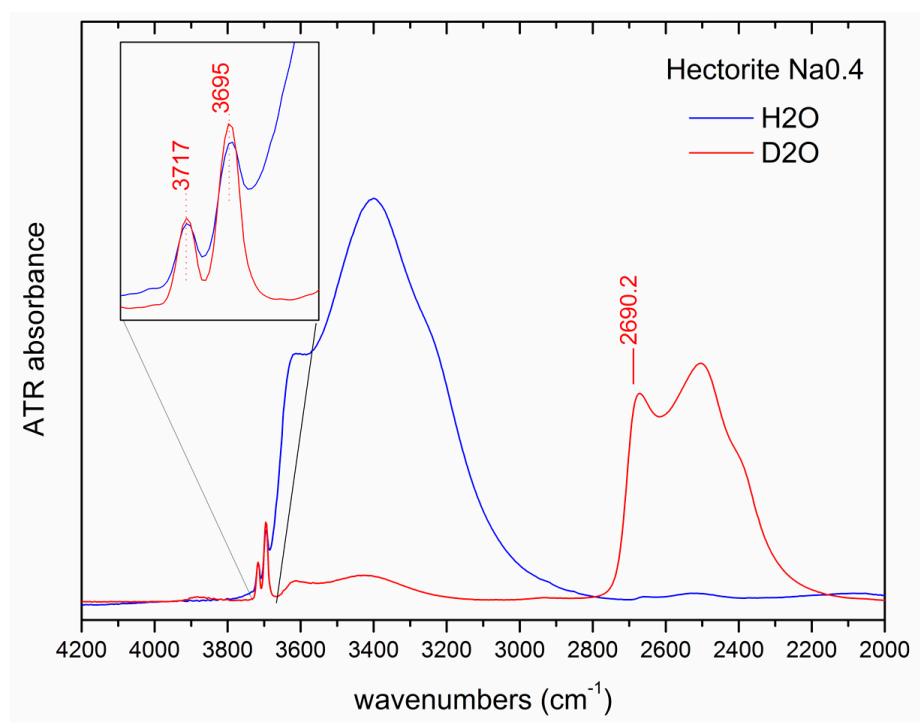

Figure 7. Detail of the ATR spectra of the synthetic hectorite $\mathrm{Na} 0.4$, fully hydrated in $\mathrm{H}_{2} \mathrm{O}$ (blue) and $\mathrm{D}_{2} \mathrm{O}$ (red). The $v \mathrm{O}-\mathrm{D}$ mode at $\sim 2690 \mathrm{~cm}^{-1}$ is displayed.

\section{Discussion}

\subsection{Characteristics of the Synthetic Mg-Li Smectites}

The XRD traces have clearly demonstrated that most of the synthetic smectites examined in this study are composite materials. The smectite composition is controlled by the experimental conditions of synthesis, with lower temperatures resulting in greater heterogeneity. The BYK-Chemie samples and the SynL-1 smectite consist of hectorite, stevensite, and a non-swelling kerolite-like phase. This heterogeneity was not obvious in the FTIR spectra, presumably because the component phases 
have comparable chemistry (e.g., kerolite and stevensite) and, also, due to the scarcity of thorough reference infrared data on natural trioctahedral smectites.

Nevertheless, the assignment of the stretching bands at $\sim 3716 / 3706,7265 / 7245 \mathrm{~cm}^{-1}$ (wet/dry) to $\mathrm{Mg}_{2} \mathrm{LiOH}$ species is an appealing possibility for identifying hectorite. These bands of interest are better defined in the fully hydrated state especially after interlayer $\mathrm{D}_{2} \mathrm{O}$ exchange which offers, additionally, a proxy for layer charge (Figure 7). KBr techniques (c.f. [38]) are not conclusive for this type of study, not only because they are not compatible with the hydrated state of the sample, but also because of the so-called "K-effect band" [40]. The $\mathrm{Mg}_{3} \mathrm{OH}$ stretching band at $\sim 3710-3720 \mathrm{~cm}^{-1}$ in saponites is observed when these are measured by $\mathrm{KBr}$ techniques or are $\mathrm{K}^{+}$-exchanged [40-42]. This band was attributed to the perturbation of the $\mathrm{OH}$ by the $\mathrm{K}^{+}$ion interacting with the localized tetrahedral charge, and is absent from talc. It is, therefore, considered as a proxy for saponite, rather than hectorite. However, the smectites examined in this study are $\mathrm{K}$-free and no $\mathrm{KBr}$ was involved in spectral acquisition. In addition, they are also Al-free and, thus, do not possess tetrahedral charge. Therefore the existence of the bands at $\sim 3716 / 3706$ and 7265/7245 might be linked with the presence of $\mathrm{Mg}_{2} \mathrm{LiOH}$. This assignment needs to be validated by the systematic study of trioctahedral smectites with variable charge and different interlayer cations.

The mineralogical composition and the structural formulae of the synthetic smectites were predicted from the chemical composition of the starting mixtures. The end-products deviated from their target mineralogical composition, with the discrepancy being greater in the low temperature hydrothermal experiments which contain non-swelling kerolite layers (first and second sample sets). Kerolite layers in the $\mathrm{OH}$-smectites might form thicker quasicrystals in aqueous and polymer suspensions, thus affecting the colloidal properties of these systems and hence their application as gelants and thickeners in various industries and in the formulation of clay polymer nanocomposites (CPNs) $[43,44]$. Although smectite layers (hectorite and stevensite) predominate in these samples, the clay concentration in suspensions necessary to obtain optimum rheological properties would have been lower, had kerolite layers been absent. In addition, the presence of kerolite layers, which are expected to form thicker quasicrystals, would hinder exfoliation during formulation of clay-polymer nanocomposites (CPNs) from both solution and melt. The fact that low-T hydrothermal XLG laponites with average particle diameters of $20 \mathrm{~nm}$ form quasicrystals up to four layers thick [22], whereas the kerolite-free synthetic hectorites similar to those of the fourth sample contain quasicrystals 1-2 layers thick [25] is compatible with this suggestion. In this aspect it is suggested that the industry optimize laponite synthesis so as to suppress formation of kerolite layers.

The layer charge obtained from the overall structural formula of Lap D, ED, and ED (0.34 e/huc) is comparable to that estimated by the FTIR VOD method $(0.38 \pm 0.02 \mathrm{e} / \mathrm{huc}$, Table 3$)$. However, the recalculated structural formula of the smectitic phase in these samples, after consideration of the presence of neutral kerolite layers, indicates a considerably higher layer charge $(0.49 \mathrm{e} / \mathrm{huc})$. The non-swelling kerolite layers might well contain vacant sites and, thus, contribute to the layer charge. However, this charge will be untraceable in both the XRD and IR analyses if it is less than $0.2 \mathrm{e} / \mathrm{huc}$, because first they would not swell in EG vapors [45] and secondly because the FTIR $v \mathrm{OD}$ method has been calibrated for layer charges down to $0.2 \mathrm{e} / \mathrm{huc}$ [31].

Nevertheless, the existence of kerolite layers with small layer charge explains partly the charge discrepancy between the two methods. Kerolite layers with layer charge $0.05 \mathrm{e} / \mathrm{huc}$ would require $0.7-0.8 \% \mathrm{Na}_{2} \mathrm{O}$ as exchangeable cation which would not belong to smectite layers (hectorite and stevensite). Simultaneously the kerolite would have less $\mathrm{Mg}$ due to the octahedral vacancies. This would allow additional $\mathrm{Mg}$ to be allocated in the smectitic phase, which would decrease the stevensitic component, because the $\mathrm{MgO}$ of the system kerolite + smectites is constant. This, in turn, would decrease layer charge of the smectite phase. In addition, part of the exchangeable $\mathrm{Na}$ in the smectite phase might reside at termination defects of the smectite crystals. This is fully compatible with the nanosize particle size of the smectite crystallites [22] and the IR data which confirm the presence of $\mathrm{SiOH}$ groups at the edge of the smectite particles (Figure 5). 
The melt derived F-smectites are kerolite-free but, based on XRD analysis, they contain minor stevensite, which was not predicted by the stoichiometry of the starting mixtures. In addition, in the Na-free samples ( $\mathrm{Li} 0.4, \mathrm{Li} 0.6, \mathrm{Li} 0.8)$ the proportion of stevensite increases with decreasing layer charge, whereas sample Na0.5 (second group) is richest in stevensite (Figure 3). Hence, melt-synthesis at temperatures in excess of $1000{ }^{\circ} \mathrm{C}[15,16]$ did not prevent the formation of octahedral vacancies suggesting that $\mathrm{Li}$ is partitioned between the octahedral sheet and the interlayer. Although the latter is

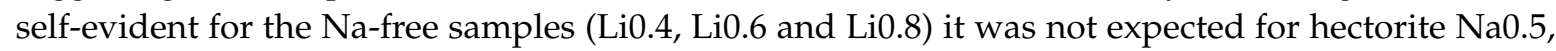
which should contain only exchangeable $\mathrm{Na}$ [16]. Subsequent annealing and hydrothermal treatment of the Na0.5 sample caused migration of exchangeable Li into the vacant octahedra, thereby converting the stevensitic to hectoritic layers. Note that this process although similar to the Hofmann-Klemen effect, does not fully neutralize the layer charge, because the vacant sites with charge deficit of $2 \mathrm{e}$ are filled by $\mathrm{Li}^{+}$, decreasing the charge deficit to $1 \mathrm{e}$, hence decreasing the layer charge as observed by the $v \mathrm{O}-\mathrm{D}$ method (Table 3). Only the high temperature hydrothermal synthesis experiments produced pure hectorite, underlining the importance of combining high temperature and pressure with prolonged time for the formation of this smectite.

Annealing at high temperature did not cause structure collapse of smectite, as might have been expected from previous thermal analysis results for natural F-bearing hectorite [33]. Early work on trioctahedral micas has shown that the $\mathrm{F}$ for $\mathrm{OH}$ substitution increases the stability of interlayer $\mathrm{K}$ by decreasing the site energy [46]. Natural hectorite and trioctahedral micas often contain both $\mathrm{OH}^{-}$and $\mathrm{F}^{-}$octahedral anions. The $\mathrm{OH}$-bearing domains decompose at lower temperatures than their F-bearing counterparts, thereby decreasing the decomposition temperature of the structure [33]. Fluorine-bearing trioctahedral micas decompose at higher temperatures than trioctahedral smectites, probably due to the existence of fixed, anhydrous interlayer cations of low hydration energy and their higher crystal order, which nevertheless are lower than the annealing temperature of the present study. The higher stability of the annealed fluorohectorite (Na0.5-ANN) is attributed to the lack of $\mathrm{OH}$-domains, which would destabilize the smectite structure due to interactions with the interlayer cations [33,46].

The aforementioned discussion indicates that the term laponite does not describe a specific mineral type of hectorite-like composition, but rather a mixture of different minerals depending on the conditions of synthesis. Some of these minerals may not contain only swelling layers. In addition the co-existence of a hectorite and stevensite layers was not recognized in previous studies (e.g., [28]). It is suggested that the term laponite should be avoided and should be replaced by the term synthetic Mg-Li phyllosilicate mixtures.

\subsection{Implications for Natural Systems}

Hectorite is a rare smectite, with extremely small number of verified outcrops worldwide. The scarcity of hectorite occurrences is attributed to the scarcity of natural Li-bearing systems coupled with hydrothermal activity. Nevertheless, even in laboratory conditions with abundant available Li and high temperatures, almost all experiments yielded end-products without octahedral Li. This suggests that the formation of hectorite might be inhibited by kinetic constraints and the existence of energy barriers that should be overcome.

The formation of smectites in nature is controlled by extreme microenvironmental heterogeneity which might lead to cryptic variations in smectite-rich horizons i.e., bentonites [47]. In Mg-rich/ $\mathrm{Al}$-poor environments stevensite is favored over kerolite at high $\mathrm{pH}$, salinity, i.e., ionic strength, and high $\mathrm{Mg} / \mathrm{Si}$ activity ratio ([48-50], among many others). Although such studies are not available for hectorite, it is reasonable to assume that similar conditions might be valid for Li-smectites and kerolite as well. The formation of stevensite and kerolite layers in Li-rich laboratory hydrothermal systems at high $\mathrm{pH}$, underlines the lack of equilibrium in these experiments. In natural Li-bearing environments, stevensite with variable number of vacancies might preferably form first due to kinetic constraints. If the number of vacancies is small enough due to microenvironmental $\mathrm{pH}$ and/or chemical heterogeneity it will 
lead to kerolite domains within stevensite, yielding stevensite/kerolite mixed layer phases. Li might replace $\mathrm{Mg}$ in smectite structure if energy barriers are overcome by hydrothermal activity during smectite formation or at a later time during diagenesis.

\section{Conclusions}

The Li-bearing smectites examined in this study are mixtures of different phases and their compositions depend on the synthesis conditions. Only high-T hydrothermal experiments yielded pure hectorite nanoparticles. The smectites produced from low temperature hydrothermal experiments contain up to $25 \%$ non-swelling kerolite layers and stevensite, except for hectorite and should be characterized as R0 mixed layer phases. The presence of a significant fraction of non-swelling kerolite layers in the low temperature hydrothermal smectites might affect the properties of these materials in industrial applications especially when dispersed in aqueous systems and in the formulation of clay-polymer nanocomposites. The melt-derived smectite nanomaterials are kerolite-free, but still contain stevensite layers. Annealing decreased the number of stevensite layers due to migration of interlayer Li to the vacant octahedral sites. The term laponite, used to describe synthetic hectorite-like smectites, should be replaced by the term synthetic Mg-Li phyllosilicate mixtures.

Author Contributions: G.E.C. coordinated the research, performed part of the XRD experiments and contributed to the writing of the manuscript; C.A. performed part of the XRD experiments and contributed to the writing of the manuscript; G.D.C. and V.G. performed the IR experiments, interpreted the IR data, and contributed to the writing of the manuscript; H.K. synthesized the Li-series smectites of the third sample set and contributed to the writing of the manuscript; M.S. synthesized the Na-series smectites of the third sample set and contributed to the writing of the manuscript; J.B. coordinated the synthesis of the smectites of the third sample set and contributed to the writing of the manuscript; and J.-L.R. synthesized the smectites of the fourth sample set.

Funding: Research was funded from EU via the IMACS Erasmus Mundus project (TUC), the Deutsche Forschungsgemeinschaft (SFB 840) (Lehrstul für Anorganische Chemie, Universität Bayreuth) and internal funding (NHRF).

Acknowledgments: George E. Christidis and Carlos Aldana wish to thank EU for funding through the IMACS Erasmus Mundus Project. We are grateful to E. Siranidi (NHRF) for expert technical assistance. Research at NHRF was financially supported by the Applied Spectroscopy Laboratory at TPCI, a provider of research services to industry. Synthesis of melt-derived F-smectites was supported by the Deutsche Forschungsgemeinschaft (SFB 840). We are grateful to BYK-Chemie for providing the laponites of the first sample set. The constructive comments of two anonymous reviewers improved the text.

Conflicts of Interest: The authors declare no conflict of interest.

\section{References}

1. Neumann, B.S. Behaviour of a Synthetic Clay in Pigment Dispersions. Rheol. Acta 1965, 4, 250-255. [CrossRef]

2. CMS Nomenclature Committee. The Clay Minerals Society Glossary of Clay Science; Part 1; The Clay Minerals Society: Chantilly, VA, USA, 2018.

3. Jaber, M.; Komarneni, S.; Zhou, C.-H. Synthesis of clay minerals. In Handbook of Clay Science, 2nd ed.; Bergaya, F., Lagaly, G., Eds.; Elsevier: Amsterdam, The Netherlands, 2013; pp. 223-240.

4. Strese, H.; Hofmann, U. Synthesis of magnesium silicate gels with two-dimensional regular structure. Zeit. Anorg. Allg. Chem. 1941, 247, 65-95. [CrossRef]

5. Caillere, S.; Oberlin, A.; Henin, S. Etude au microscope electronique de quelques silicates phylliteux obtenus par syntheses a basse temperature. Clay Miner. Bull. 1954, 2, 146-156. [CrossRef]

6. Henin, S. Synthesis of clay minerals at low temperatures. Clays Clay Miner. 1956, 4, 54-60. [CrossRef]

7. Granquist, W.T.; Pollack, S.S. A study of the synthesis of hectorite. Clays Clay Miner. 1960, 8, 150-169. [CrossRef]

8. Harder, H. Clay mineral formation under lateritic weathering conditions. Clay Miner. 1977, 12, $281-288$. [CrossRef]

9. Decarreau, A. Cristallogenese expdrimentale des smectites magnesiennes: Hectorite, stevensite. Bull. Mineral. 1980, 103, 579-590.

10. Saunders, J.M.; Goodwin, J.W.; Richardson, R.M.; Vincent, B. A small-angle X-ray scattering study of the structure of aqueous laponite dispersions. J. Phys. Chem. B 1999, 103, 9211-9218. [CrossRef] 
11. Breu, J.; Seidl, W.; Stoll, A.J.; Lange, K.G.; Probst, T.U. Charge homogeneity in synthetic fluorohectorite. Chem. Mater. 2001, 13, 4213-4220. [CrossRef]

12. Zhou, C.H.; Du, Z.X.; Li, X.N.; Lu, C.S.; Ge, Z.H. Structure development of hectorite in hydrothermal crystallization synthesis process. Chin. J. Inorg. Chem. 2005, 21, 1327-1332.

13. Malikova, N.; Cadene, A.; Dubois, E.; Marry, V.; Durand-Vidal, S.; Turq, P.; Breu, J.; Longeville, S.; Zanotti, J.-M. Water diffusion in a synthetic hectorite clay studied by quasielastic neutron scattering. J. Phys. Chem. C 2007, 111, 17603-17611. [CrossRef]

14. Kalo, H.; Moller, M.W.; Ziadeh, M.; Dolejs, D.; Breu, J. Large scale melt synthesis in an open crucible of Na-fluorohectorite with superb charge homogeneity and particle size. Appl. Clay Sci. 2010, 48, 39-45. [CrossRef]

15. Kalo, H.; Möller, M.W.; Kunz, D.A.; Breu, J. How to Maximize the Aspect Ratio of Clay Nanoplatelets. Nanoscale 2012, 4, 5633-5639. [CrossRef] [PubMed]

16. Stöter, M.; Kunz, D.A.; Schmidt, M.; Hirsemann, D.; Kalo, H.; Putz, B.; Senker, J.; Breu, J. Nanoplatelets of Sodium Hectorite Showing Aspect Ratios of $\approx 20,000$ and Superior Purity. Langmuir 2013, 29, 1280-1285. [CrossRef] [PubMed]

17. Kloprogge, J.T.; Komarneni, S.; Amonette, J.E. Synthesis of smectite clay minerals: A critical review. Clays Clay Miner. 1999, 47, 529-554. [CrossRef]

18. Zhang, D.; Zhou, C.-H.; Lin, C.-X.; Tong, D.-S.; Yu, W.-H. The synthesis of clay minerals. Appl. Clay Sci. 2010, 50, 1-11. [CrossRef]

19. Carrado, K.A. Synthetic organo- and polymer-clays: Preparation, characterization, and materials applications. Appl. Clay Sci. 2000, 17, 1-23. [CrossRef]

20. Christidis, G.E. Industrial Minerals: Significance and Important Characteristics. In Advances in the characterization of Industrial Minerals; Christidis, G.E., Ed.; EMU Notes in Mineralogy; Mineralogical Society: London, UK, 2011; Volume 9, pp. 1-12.

21. Thomas, F.; Michot, L.J.; Vantelon, D.; Montarges, E.; Prelot, B.; Cruchaudet, M.; Delon, J.F. Layer charge and electrophoretic mobility of smectites. Colloids Surf. A 1999, 159, 351-358. [CrossRef]

22. Thompson, D.W.; Butterworth, J.T. The nature of laponite and its aqueous dispersions. J. Colloid Interface Sci. 1992, 151, 236-243. [CrossRef]

23. Kroon, M.; Vos, W.L.; Wedgam, G.H. Structure and formation of a gel of colloidal disks. Phys. Rev. E 1998, 57, 1962-1970. [CrossRef]

24. Nikolai, T.; Cocard, S. Light Scattering Study of the Dispersion of Laponite. Langmuir 2000, 16, 8189-8193. [CrossRef]

25. Vantelon, D.; Belkhou, R.; Bihannic, I.; Michot, L.J.; Montargès-Pelletier, E.; Robert, J.-L. An XPEEM study of structural cation distribution in swelling clays. I. Synthetic trioctahedral smectites. Phys. Chem. Miner. 2009, 36, 593-602. [CrossRef]

26. Christidis, G.E.; Koutsopoulou, E. A simple approach to the identification of trioctahedral smectites by X-ray diffraction. Clay Miner. 2013, 48, 687-696. [CrossRef]

27. Neumann, B.S.; Sansom, K.G. The formation of stable sols from laponite, a synthetic hectorite-like clay. Clay Miner. 1965, 8, 389-404. [CrossRef]

28. Bärwinkel, K.; Markus, M.M.; Rieß, M.; Sato, H.; Li, L.; Avadhut, Y.S.; Kemnitzer, T.W.; Hussein Kalo, H.; Senker, J.; Matsuda, R.; et al. Constant Volume Gate-Opening by Freezing Rotational Dynamics in Microporous Organically Pillared Layered Silicates. J. Am. Chem. Soc. 2017, 139, 904-909. [CrossRef] [PubMed]

29. Karmous, M.S.; Samira, J.; Robert, J.-L.; Ben Haj Amara, A. Nature of disorder in synthetic hectorite. Appl. Clay Sci. 2009, 51, 23-32. [CrossRef]

30. Bukas, V.J.; Tsampodimou, M.; Gionis, V.; Chryssikos, G.D. Synchronous ATR infrared and NIR-spectroscopy investigation of sepiolite upon drying. Vibr. Spectr. 2013, 68, 51-60. [CrossRef]

31. Kuligiewicz, A.; Derkowski, A.; Emmerich, K.; Christidis, G.E.; Tsiantos, C.; Gionis, V.; Chryssikos, G.D. Measuring the layer charge of dioctahedral smectite by O-D vibrational spectroscopy. Clays Clay Miner. 2015, 63, 443-456. [CrossRef]

32. MacEwan, D.M.C.; Wilson, M.J. Interlayer and intercalation complexes of clay minerals. In Crystal Structures of Clay Minerals and Their X-Ray Identification; Bindley, G.W., Brown, G., Eds.; Mineralogical Society: London, UK, 1984; pp. 187-248. 
33. Chipera, S.J.; Bish, D.L. Thermal evolution of fluorine from smectite and kaolinite. Clays Clay Miner. 2002, 50, 38-46. [CrossRef]

34. Reynolds, R.C., Jr.; Reynolds, R.C., III. Newmod-for-Windows. The Calculation of One-Dimensional X-ray Diffraction Patterns of Mixed-Layered Clay Minerals; Computer Program: Hanover, NH, USA, 1996.

35. Brindley, G.W.; Bish, D.L.; Wan, H.-M. The nature of kerolite and its relation to talc and stevensite. Mineral. Mag. 1977, 41, 443-452. [CrossRef]

36. Stathopoulou, E.T.; Suárez, M.; García-Romero, E.; Sánchez del Río, M.; Kacandes, G.H.; Gionis, V.; Chryssikos, G.D. Trioctahedral entities in palygorskite: Near-infrared evidence for sepiolite/palygorskite polysomatism. Eur. J. Mineral. 2011, 23, 567-576. [CrossRef]

37. Prost, R. Etude de $\mathrm{l}^{\prime}$ hydratation des argiles: Interactions eau-minéral et mécanisme de la rétention de $\mathrm{l}^{\prime}$ eau. Ann. Agron. 1975, 26, 401-461.

38. Pálková, H.; Madejová, J.; Zimowska, M.; Serwicka, E.W. Laponite-derived porous clay heterostructures: II. FTIR study of the structure evolution. Microporous Mesoporous Mater. 2010, 127, 237-244. [CrossRef]

39. Ras, R.H.A.; Johnston, C.T.; Franses, E.I.; Ramaekers, R.; Maes, G.; Foubert, P.; De Schryver, F.C.; Schoonheydt, R.A. Polarized infrared study of hybrid Langmuir-Blodgett monolayers containing clay mineral nanoparticles. Langmuir 2003, 19, 4295-4302. [CrossRef]

40. Russell, J.D.; Fraser, A.R. Infrared methods. In Clay Minerals, Spectroscopic and Chemical Determinative Methods; Wilson, M.J., Ed.; Springer: Heidelberg, Germany, 1994; pp. 11-67.

41. Pelletier, M.; Michot, L.J.; Barrès, O.; Humbert, B.; Petit, S.; Robert, J.-L. Influence of KBr conditioning on the infrared hydroxyl-stretching region of saponites. Clay Miner. 1999, 34, 439-445. [CrossRef]

42. Pelletier, M.; Michot, L.J.; Humbert, B.; Barrès, O.; D’ Espinose de la Caillerie, J.-B.; Robert, J.-L. Influence of layer charge on the hydroxyl stretching of trioctahedral clay minerals: A vibrational study of synthetic Naand K-saponites. Amer. Mineral. 2003, 88, 1801-1808. [CrossRef]

43. Theng, B.K.G. Polymer-Clay Nanocomposites. In Formation and Properties of Clay-Polymer Complexes; Developments in Clay Science; Theng, B.K.G., Eds.; Elsevier: Amsterdam, The Netherlands, 2011; pp. 201-241.

44. Carrado, K.A.; Komadel, P. Acid activation of bentonites and polymer-clay nanocomposites. Elements 2009, 5, 111-116. [CrossRef]

45. Skoubris, E.N.; Chryssikos, G.D.; Christidis, G.E.; Gionis, V. Structural characterization of reduced charge montmorillonites. Evidence based on FTIR spectroscopy, thermal behavior and layer charge systematics. Clays Clay Miner. 2013, 61, 83-97. [CrossRef]

46. Giese, R.F., Jr. The effect of F/OH substitution on some layer-silicate minerals. Zeitschrift für Kristallographie 1975, 138, 138-144. [CrossRef]

47. Christidis, G.E.; Huff, W.D. Geological Aspects and Genesis of Bentonites. Elements 2009, 5, 93-98. [CrossRef]

48. Pozo, M.; Casas, J. Origin of kerolite and associated Mg clays in palustrine-lacustrine environments; the Esquivias Deposit (Neogene Madrid Basin, Spain). Clay Miner. 1999, 34, 395-418. [CrossRef]

49. Galan, E.; Palygorskite, P.M.; Sepiolite Deposits in Continental Environments. Description, genetic patterns and sedimentary settings. In Developments in Palygorskite-Sepiolite Research; Developments in Clay Science; Galan, E., Singer, A., Eds.; Elsevier: Amsterdam, The Netherlands, 2011; pp. 125-173.

50. Tosca, N.J.; Masterson, A.L. Chemical controls on incipient Mg-silicate crystallization at $25{ }^{\circ} \mathrm{C}$ : Implications for early and late diagenesis. Clay Miner. 2014, 49, 165-194. [CrossRef]

(C) 2018 by the authors. Licensee MDPI, Basel, Switzerland. This article is an open access article distributed under the terms and conditions of the Creative Commons Attribution (CC BY) license (http://creativecommons.org/licenses/by/4.0/). 